\title{
CORONAVIRUS
}

\section{C-like protease inhibitors block coronavirus replication in vitro and improve survival in MERS-CoV-infected mice}

\author{
Athri D. Rathnayake ${ }^{1 *}$, Jian Zheng', Yunjeong Kim³ ${ }^{3}$, Krishani Dinali Perera ${ }^{3}$, Samantha Mackin ${ }^{2}$, David K \\ Meyerholz ${ }^{4}$, Maithri M. Kashipathy ${ }^{5}$, Kevin P. Battaile ${ }^{6}$, Scott Lovell ${ }^{5}$, Stanley Perlman' ${ }^{\dagger}$, William C. Groutas ${ }^{1} \uparrow$, \\ Kyeong-Ok Chang ${ }^{3} \dagger$ \\ ${ }^{1}$ Department of Chemistry, Wichita State University, Wichita, Kansas 67260, USA. ${ }^{2}$ Department of Microbiology and Immunology, University of lowa, lowa City, IA 52242 , \\ USA. ${ }^{3}$ Department of Diagnostic Medicine \& Pathobiology, College of Veterinary Medicine, Kansas State University, Manhattan, Kansas 66506, USA. ${ }^{4}$ Department of \\ Pathology, University of lowa, lowa City, IA 52242, USA. ${ }^{5}$ Protein Structure Laboratory, The University of Kansas, Lawrence, Kansas 66047, USA. ${ }^{6}$ NYX, New York \\ Structural Biology Center, Upton, NY 11973, USA. \\ *these authors have contributed equally. \\ fauthors to whom correspondence should be addressed. Emails: kchang@vet.ksu.edu, stanley-perlman@uiowa.edu, bill.groutas@wichita.edu
}

Pathogenic coronaviruses are a major threat to global public health, as exemplified by Severe Acute Respiratory Syndrome coronavirus (SARS-CoV), Middle East respiratory syndrome coronavirus (MERS$\mathrm{CoV}$ ) and the newly emerged SARS-CoV-2, the causative agent of coronavirus disease 2019 (COVID-19). We describe herein the structure-guided optimization of a series of inhibitors of the coronavirus $3 \mathrm{C}$-like protease (3CLpro), an enzyme essential for viral replication. The optimized compounds were effective against several human coronaviruses including MERS-CoV, SARS-CoV and SARS-CoV-2 in an enzyme assay and in cell-based assays using Huh-7 and Vero E6 cell lines. Two selected compounds showed antiviral effects against SARS-CoV-2 in cultured primary human airway epithelial cells. In a mouse model of MERSCoV infection, administration of a lead compound one day after virus infection increased survival from 0 to $100 \%$ and reduced lung viral titers and lung histopathology. These results suggest that this series of compounds has the potential to be developed further as antiviral drugs against human coronaviruses.

\section{INTRODUCTION}

Coronaviruses are a large group of viruses that can cause a wide variety of diseases in humans and animals (1). Human coronaviruses generally cause the common cold, a mild upper respiratory illness. However, global outbreaks of new human coronavirus infections with severe respiratory disease have periodically emerged from animal reservoirs, including Severe Acute Respiratory Syndrome coronavirus (SARS-CoV), Middle East Respiratory Syndrome coronavirus (MERS-CoV) and, most recently, SARS-CoV-2, the causative agent of coronavirus disease 2019 (COVID-19). SARS-CoV-2 emerged in China in December 2019 and subsequently rapidly spread throughout the world. Genetic analysis of SARS-CoV-2 revealed that it is closely related to SARS-like beta-coronaviruses of bat origin, bat-SL-CoVZC45 and bat-SL-CoVZXC21 (2). Despite the periodic emergence of new coronaviruses capable of infecting humans, there are currently no licensed vaccines or antiviral drugs against any coronaviruses, underscoring the urgent need for the development of preventive and therapeutic measures against pathogenic coronaviruses.

The coronavirus genome contains two overlapping open reading frames (ORF1a and $O R F 1 b)$ at the $5^{\prime}$ end terminal, which encode polyproteins ppla and pplab. The polyproteins are processed by a 3C-like protease (3CLpro or Main protease, MPro) (11 cleavage sites) and a papain-like protease (PLpro) (3 cleavage sites), resulting in sixteen mature nonstructural proteins, including an RNA-dependent RNA polymerase (RdRp). Both 3CLpro and PLpro are essential for viral replication, making them attractive targets for drug development (3-7). Coronavirus 3CLpro is a cysteine protease that has two $\mathrm{N}$-terminal domains containing two $\beta$-barrel chymotrypsinlike folds (8-10). The active site of 3CLpro is located in the cleft between the two domains and is characterized by a catalytic Cys-His dyad.

We have developed broad-spectrum inhibitors of an array of viruses, including coronaviruses and noroviruses (11-18) that use 3CLpro for viral replication and picornaviruses that use $3 \mathrm{C}$ protease (19). We have shown efficacy of the coronavirus 3CLpro inhibitor, GC376 (currently in clinical development) in animal models of coronavirus infection $(20,21)$. Specifically, administration of GC376 to cats with feline infectious peritonitis (FIP), a coronavirus-induced systemic disease that is $100 \%$ fatal, reversed the progression of FIP and resulted in clinical remission $(20,21)$. We have recently 
reported the results of exploratory in vitro studies using a dipeptidyl series of MERS-CoV 3CLpro inhibitors that embody a piperidine moiety as a new design element, as well as pertinent structural and biochemical studies (17). Here, we report the development of 3CLpro inhibitors against multiple coronaviruses, including SARS-CoV-2, and demonstrate in vivo efficacy against MERS-CoV in a mouse model.

\section{RESULTS}

\section{CLpro inhibitors show activity against multiple coro- naviruses in enzyme and cell-based assays}

The synthesis scheme for compound series $\mathbf{6 a}-\boldsymbol{k}$ and $\mathbf{7 a -}$ $\boldsymbol{k}$ is shown in Fig. 1 and described in the supplementary materials and methods. The activity of compounds $\mathbf{6 a - k}$ and $7 \boldsymbol{a}$ $\boldsymbol{k}$ against the 3CLpro enzymes of MERS-CoV, SARS-CoV and SARS-CoV-2 was evaluated in a fluorescence resonance energy transfer (FRET) enzyme assay (Table 1, Table S1). Several compounds in this series $(\boldsymbol{6 a}, 7 \boldsymbol{a}, \mathbf{6 c}, 7 \boldsymbol{c}, \mathbf{6 e}, \mathbf{7 e}, \mathbf{6 h}, \mathbf{7 h}, \mathbf{6 j}$ and 7j) were also tested in cell-based assays (Table 2). Table 1 and Table S1 show 50\% inhibitory concentration $\left(\mathrm{IC}_{50}\right)$ values in a FRET enzyme assay for select compounds $(\boldsymbol{6 a}, 7 \boldsymbol{a}$, $\boldsymbol{6 c}, \mathbf{7 c}, \mathbf{6 e}, \mathbf{7 e}, \mathbf{6 h}, \mathbf{7 h}, \mathbf{6 j}$ and $7 \boldsymbol{j})$ and GC376. 50\% effective concentration $\left(\mathrm{EC}_{50}\right)$ values and $50 \%$ cytotoxic concentration $\left(\mathrm{CC}_{50}\right)$ values for select compounds and GC376 were measured in cell culture assays (Table 2). Cell culture assays included Huh7 cells infected with MERS-CoV, Vero E6 cells infected with SARS-CoV-2, CRFK cells infected with feline infectious peritonitis virus (FIPV) and CCL1 cells infected with mouse hepatitis virus (MHV) (Table 2). Inhibitors with a $\mathrm{P}_{2}$ leucine (Leu) residue were more potent than those with a cyclohexylalanine against MERS-CoV 3CLpro (compounds $\boldsymbol{6 h}$ and $\boldsymbol{7 h}$ versus $\boldsymbol{6 i}$ and $\boldsymbol{7 i}$ ), with submicromolar IC $_{50}$ values (Table 1, Table S1). The compounds tested against MERS-CoV in cell culture (7a, $6 \boldsymbol{c}, \boldsymbol{7 e}, \boldsymbol{7 h}$ and $\mathbf{6 j})$ also displayed submicromolar $\mathrm{EC}_{50}$ values. Among these compounds, $\boldsymbol{6} \boldsymbol{j}$ showed the most potent antiviral activity against MERS-CoV with an $\mathrm{EC}_{50}$ value of $0.04 \mu \mathrm{M}$. GC376 with a $\mathrm{P}_{2}$ Leu residue and a nonfluorinated benzyl cap, exhibited 20-fold lower potency against MERS-CoV in cell culture compared to compound $\boldsymbol{6} \boldsymbol{j}$ (Table 2).

The compounds were also effective against SARS-CoV-2 with $\mathrm{EC}_{50}$ values ranging from 0.15 to $0.9 \mu \mathrm{M}$ in Vero E6 cells (Table 2). These compounds were also found to be potent against FIPV and $\mathrm{MHV}$, with $\mathrm{EC}_{50}$ values ranging from 0.07 to $0.22 \mu \mathrm{M}$. In the FRET enzyme assay, these compounds were active against the 3CLpro of SARS-CoV and SARS-CoV2 (Table 1). The $\mathrm{IC}_{50}$ values of these compounds against SARSCoV-2 3CLpro ranged from 0.17 to $0.82 \mu \mathrm{M}$. Among these compounds, $\boldsymbol{6} \boldsymbol{e}$ showed the most potent antiviral activity against SARS-CoV-2 in the enzyme assay $\left(\mathrm{IC}_{50}, 0.17 \mu \mathrm{M}\right)$ and cell-based assay ( $\mathrm{IC}_{50}, 0.15 \mu \mathrm{M}$ ) (Tables 1 and 2). Notably, GC376 also exhibited activity against the 3CLpro of SARS-
CoV-2 with an $\mathrm{IC}_{50}$ value of $0.62 \mu \mathrm{M}$ in the enzyme assay (Table 1).

The antiviral effects of compounds $\boldsymbol{6} \boldsymbol{j}$ and $\boldsymbol{6} \boldsymbol{e}$ against SARS-CoV-2 were confirmed in cultured primary human airway epithelial cells from 3 donors, who were infected with SARS-CoV-2. In the absence of a 3CLpro inhibitor, viral titers in the infected cultured primary human airway epithelial cells reached $10^{7.3}$ (donor 1 ), $10^{7.1}$ (donor 2 ), $10^{8.4}$ (donor 3 ) plaque forming units ( $\mathrm{pfu}$ ) per $\mathrm{ml}$ of culture medium. In the presence of compound concentrations that were approximately 2-3 fold higher than the $\mathrm{EC}_{50}$ values obtained in cultured cells $(2 \mu \mathrm{M}, \boldsymbol{6} \boldsymbol{j}$ or $0.5 \mu \mathrm{M}, \boldsymbol{6} \boldsymbol{e})$, viral titers were reduced to $10^{6.4}$ (donor 1 ), $10^{6.1}$ (donor 2 ), $10^{6.3}$ (donor 3 ) $\mathrm{pfu} / \mathrm{ml}$ for compound $\boldsymbol{6} \boldsymbol{j}$, or $10^{6.1}$ (donor 1 ), $10^{6.5}$ (donor 2 ), $10^{8.1}$ (donor 3 ) $\mathrm{pfu} / \mathrm{ml}$ for compound $\boldsymbol{6} \boldsymbol{e}$ (Table 3 ). Although there was some variation in viral replication among infected cells from the three donors (especially donor 3), the antiviral effects of both $\boldsymbol{6} \boldsymbol{j}$ and $\boldsymbol{6} \boldsymbol{e}$ were evident at the tested concentrations. For infected cells from donors 1 and 2, both compounds inhibited viral replication approximately 10 -fold at the tested concentrations. For infected cells from donor $3, \boldsymbol{6} \boldsymbol{e}$ inhibited virus replication approximately $50 \%$, whereas $\boldsymbol{6} \boldsymbol{j}$ inhibited virus replication 100-fold at the tested concentrations.

\section{Co-crystal structures for 3CLpro of MERS-CoV, SARS- CoV and SARS-CoV-2 with 3CLpro inhibitors}

We determined multiple high-resolution cocrystal structures of compounds $\boldsymbol{6 b}, \boldsymbol{6 d}, \boldsymbol{6} \mathbf{g}, \boldsymbol{6 h}, \boldsymbol{7 i}$ or $\boldsymbol{7 j}$ with the 3CLpro of MERS-CoV (Fig. 2A-F, Fig. S1-S3). These inhibitors bound to the active site of MERS-CoV 3CLpro demonstrating that the vicinity of the $S_{4}$ pocket is encompassed by an array of primarily hydrophobic residues, including Phe188, Val193, Ala171, and Leu170 (Fig. 2C, 2F and Fig. S3). Hydrophobic and hydrogen-bonding functionalities were incorporated into the 3CLpro inhibitors to capture additional interactions, and the position of the cyclohexyl moiety was also examined using appropriate congeners. The bisulfite adducts reverted to the corresponding aldehydes, which subsequently reacted with Cys148 to form nearly identical covalent complexes with a tetrahedral arrangement at the newly-formed stereocenter (Fig. 2A-F and Fig. S1-S3). The backbone of compound $\boldsymbol{6 h}$ (Table 1 and Fig. 2A-C) engaged in $\mathrm{H}$-bond interactions with amino acid residues Gln192, Gln167 and Glu169. Three additional side chain $\mathrm{H}$-bonds between the $\mathrm{\gamma}$-lactam ring and His166, Phe143 and Glu169 also were clearly evident (Fig. 2B). Furthermore, the side chain of the $\mathrm{P}_{2}$ Leu was ensconced in the hydrophobic $S_{2}$ pocket (Fig. $2 \mathrm{C}$ ). The extra methylene group in compound $\mathbf{7 j}$, which was converted to an aldehyde and thus became identical to $\boldsymbol{6} \boldsymbol{j}$, resulted in re-orientation of the difluorocyclohexyl group and the formation of three H-bonds between Gln195 and Ala171 and the fluorine atoms, with concomitant loss of one of the Gln192 hydrogen bonds and the displacement of Phe143 (Fig. 2E). The substitution of the P2 
Leu with P2 cyclohexylalanine (compound $\boldsymbol{7 i}$, Table S1) resulted in the loss of an H-bond with Gln192, but otherwise adopted the same interactions as observed for compound $\boldsymbol{6 h}$ (Fig. S2A). The electron density, hydrogen bond interactions and electrostatic surface representations for MERS-CoV 3CLpro in complex with compounds $\boldsymbol{6 b}, \boldsymbol{G} \boldsymbol{g}$ and $\boldsymbol{6 \boldsymbol { d }}$ are shown in Fig. S1-S3.

Next, compound $\boldsymbol{7 j}$ was cocrystallized with SARS-CoV or SARS-CoV-2 3CLpro and the structures were compared to that for MERS-CoV 3CLpro and $7 \boldsymbol{j}$. In the SARS-CoV 3CLpro$\boldsymbol{z} \boldsymbol{j}$ complex (Fig. 2G-I), the backbone of compound $\boldsymbol{\eta} \boldsymbol{j}$ formed direct H-bonds with Cys145, His163, His164, Glu166, and Gln189. Compound $\boldsymbol{\eta} \boldsymbol{j}$ also formed an additional H-bond with His41 and a water-mediated contact with Gly143 (Fig. 2H). However, there was a loss of the three H-bonds between Gln195 and Ala171 and the fluorine atoms, compared to the cocrystal structure of $\boldsymbol{\eta} \boldsymbol{j}$ with MERS-CoV 3CLpro. Notably, the electron density map was consistent with both possible enantiomers at the new stereocenter formed by covalent attachment of the $S_{\curlyvee}$ atom of Cys145 in the cocrystal structure of SARS-CoV 3CLpro with $\boldsymbol{7 j}$. The electron density map for compound $\boldsymbol{7 j}$ in complex with SARS-CoV-2 3CLpro was most consistent with a single enantiomer, although it adopted a similar binding mode and hydrogen bond interactions as observed in the SARS-CoV 3CLpro-7j cocrystal structure (Fig. $2 \mathrm{~J}-\mathrm{L})$. Superposition of compound $\boldsymbol{7 j}$ with MERS-CoV 3CLpro, SARS-CoV 3CLpro and SARS-CoV-2 3CLpro (Fig. S4) revealed a very similar binding mode for $\boldsymbol{\eta} \boldsymbol{j}$ among all three viral proteases.

\section{CLpro inhibitor treatment increases survival and re- duces lung viral load in infected hDPP4-KI mice}

The most potent compound of the series, $\boldsymbol{6} \boldsymbol{j}$, was identified in a cell-based assay and had an $\mathrm{EC}_{50}$ value of $0.04 \mu \mathrm{M}$ against MERS-CoV (Fig. 3A). We determined the efficacy of compounds $\boldsymbol{6} \boldsymbol{j}$ and $\boldsymbol{\sigma} \boldsymbol{h}$ in transgenic hDPP4-KI mice expressing human dipeptidylpeptidase 4 , a model of MERS-CoV infection. First, hDPP4-KI mice were infected with the mouseadapted MERS-CoV (MERS MA $\left._{-} \mathrm{CoV}\right)$ virus strain and then were treated with compounds $\boldsymbol{6} \boldsymbol{h}, \boldsymbol{6} \boldsymbol{j}(50 \mathrm{mg} / \mathrm{kg} /$ day, once a day) or vehicle as a control starting one day post virus infection (1 dpi) and continuing until $10 \mathrm{dpi}$. All mice treated with vehicle control died by 8 dpi (Fig. 3B). In contrast, $40 \%$ of mice treated with compound $\boldsymbol{6 h}$ survived, and all mice treated with compound $\boldsymbol{6} \boldsymbol{j}$ were alive at the end of the study (15 dpi) (Fig. 3B). The survival of mice treated with compound $\boldsymbol{6 j}$ or $\boldsymbol{6 h}$ was increased compared to the vehicle control $(\mathrm{p}<0.05)$, and the $\boldsymbol{6} \boldsymbol{j}$-treated mice had an improved survival rate compared to $\boldsymbol{G} \boldsymbol{h}$-treated mice $(\mathrm{p}<0.05)$. All mice treated with compound $\boldsymbol{6} \boldsymbol{j}$ rapidly recovered from body weight loss starting at $3 \mathrm{dpi}$ (Fig. 3C). The mice that survived after $\mathbf{6 h}$ treatment continued to lose body weight until $6 \mathrm{dpi}$, but then started to gain weight from 9 dpi (Fig. 3C).
After we observed that treatment with compound $\boldsymbol{6} \boldsymbol{j}$ resulted in the survival of $\mathrm{MERS}_{\mathrm{MA}}-\mathrm{CoV}$-infected hDPP4-KI mice, we conducted another study by delaying treatment initiation until $3 \mathrm{dpi}$. Similar to the first study, no untreated mice or mice given vehicle (control) survived, and there was no statistical difference between these two groups $(0 \%$ survival) (Fig. 3D). When $\boldsymbol{6} \boldsymbol{j}$ treatment was started on $1 \mathrm{dpi}$, four of the five mice survived ( $80 \%$ survival), and there was a statistically significant increased survival in mice treated starting at $1 \mathrm{dpi}$ compared to untreated or vehicle control-treated mice $(\mathrm{P}<0.05$, Fig. 3D). When $\boldsymbol{6} \boldsymbol{j}$ treatment was delayed by one additional day ( $2 \mathrm{dpi}$ ), the survival of mice treated with $\boldsymbol{6 j}$ decreased to $40 \%$, but this was still higher than $0 \%$ survival for untreated or vehicle control-treated mice. However, there was no statistical difference between the $\boldsymbol{6} \boldsymbol{j}$ treatment group starting at $2 \mathrm{dpi}$ and the untreated or vehicle controltreated groups (Fig. 3D). Treatment with $\boldsymbol{6} \boldsymbol{j}$ starting at $3 \mathrm{dpi}$ also failed to improve the survival of mice compared to the untreated or vehicle control-treated groups (Fig. 3D). All mice lost body weight following virus infection, but surviving mice treated with $\boldsymbol{6} \boldsymbol{j}$ regained the lost weight by $15 \mathrm{dpi}$ (Fig. 3E). Recovery of body weight was faster in mice treated with $\boldsymbol{6} \boldsymbol{j}$ starting at $1 \mathrm{dpi}$ than at $2 \mathrm{dpi}$ (Fig. 3E). These results show that survival of mice markedly increased when $\boldsymbol{6} \boldsymbol{j}$ was given at $1 \mathrm{dpi}$. The antiviral effect of $\boldsymbol{6} \boldsymbol{j}$ in this mouse model was greater than that of $\boldsymbol{\sigma} \boldsymbol{h}$ with better survival rates and faster recovery of body weight in the $\boldsymbol{6} \boldsymbol{j}$-treated group (Fig. 3D, E).

\section{Treating infected hDPP4-KI mice with compound $6 \mathbf{j}$ re- duces lung viral titers}

The lung pathology caused by $\mathrm{MERS}_{\mathrm{MA}}-\mathrm{CoV}$ infection of hDPP4-KI mice resembles that seen in severe cases of human MERS-CoV infection, with diffuse alveolar damage, pulmonary edema, hyaline membrane formation, and infiltration of lymphocytes into the alveolar septa (22). A group of hDPP4KI mice were infected with $\mathrm{MERS}_{\mathrm{MA}}-\mathrm{CoV}$ and treated with compound $\boldsymbol{6} \boldsymbol{j}$ or vehicle as a control starting at $1 \mathrm{dpi}$. Mouse lungs were collected for determination of virus load at 3 and $5 \mathrm{dpi}$, and for histopathology at $6 \mathrm{dpi}$. Lung virus titers decreased in the $\boldsymbol{6} \boldsymbol{j}$-treated mice compared to control mice at both 3 and 5 dpi $(\mathrm{P}<0.01)$ (Fig. 4A). Edema in the lungs of the treated mice was reduced compared to control mice $(\mathrm{P}<0.01)$ (Fig. 4B). Scores for hyaline membrane formation were reduced in $\boldsymbol{6} \boldsymbol{j}$-treated mice but were not statistically different from control mice. $\mathrm{MERS}_{\mathrm{MA}} \mathrm{-CoV}$-infected hDPP4-KI mice treated with vehicle showed patches in lung tissue variably composed of cellular inflammation, vascular congestion, and atelectasis (Fig. 4C and E). The airways of these animals were generally intact, with only scattered, uncommon sloughed cells (Fig. 4C and E). In some lungs from these mice, lymphatic vessels were filled with degenerative cells and cellular debris (Fig. 4C and E). Alveolar edema was detected in some lung tissue sections (Fig. 4C and E). In contrast, there were 
few observed lesions in the lungs of MERS $\mathrm{MA}_{\mathrm{MA}} \mathrm{CoV}$-infected hDPP4-KI mice treated with compound $\boldsymbol{6} \boldsymbol{j}$ starting at $1 \mathrm{dpi}$ (Fig. 4D and F).

\section{DISCUSSION}

There are currently no approved vaccines or small molecule therapeutics for the treatment of MERS-CoV, SARS-CoV or SARS-CoV-2 infection. However, numerous preventive and therapeutic options are under development (3-7). The most clinically-advanced antiviral compound with a broad-spectrum of activity is remdesivir (GS-5734). This nucleoside ana$\log$ originally was developed as an antiviral drug against Ebola virus and has been shown to be effective against both MERS-CoV and SARS-CoV in cell culture assays and in animal models of coronavirus infection (23-26). Prophylactic treatment or early therapeutic treatment of infected mice with remdesivir reduced MERS-CoV or SARS-CoV-mediated weight loss and decreased lung virus titers and lung injury scores compared to vehicle-treated animals $(23,26)$. Remdesvir also showed potent activity against SARS-CoV-2 in cell culture assays and animal models (27), and was recently issued emergency use authorization by the US Food and Drug Administration as an investigational antiviral drug for COVID-19. Another nucleoside analog, EIDD-2801, which is a broad-spectrum inhibitor against multiple viruses including influenza viruses, was also shown to be effective against MERS-CoV and SARS-CoV in mouse models (28).

Our group has been engaged in the discovery of broadspectrum inhibitors targeting the 3CLpro of multiple human and animal coronaviruses. We initially generated dipeptidyl and tripeptidyl series of compounds (29) and observed that the dipeptidyl compound series had superior pharmacokinetic (PK) profiles compared to the tripeptidyl compound series (20). A representative compound of the dipeptidyl series is GC376, which is currently in clinical development for FIP in cats and COVID-19. The PK characteristics of multiple dipeptidyl compounds similar to compound $\boldsymbol{6} \boldsymbol{j}$, including GC376, were examined through intraperitoneal or subcutaneous administration in animals, including mice. It was determined that their $\mathrm{C}_{\max }$ values were $>100$-fold of the $\mathrm{EC}_{50}$ for the target virus, and that the elimination half-life $\left(\mathrm{T}_{1 / 2}\right)$ was 35 hours. The in vivo efficacy of GC376 against mice infected with MHV or murine norovirus has been demonstrated (11, 15).

Inspection of previously-obtained crystal structures of the dipeptidyl compounds in a complex with coronavirus 3CLpro $(17,19)$ revealed the potential to achieve enhanced binding interactions with the $\mathrm{S}_{4}$ subsite by introducing diverse functionalities at the cap position in the inhibitors. In the current study, a new dipeptidyl series focusing on the design of structural variants in the cap substructure were synthesized and evaluated for their activity against coronavirus 3CLpro. The
$\mathrm{EC}_{50}$ of GC376 against MERS-CoV was determined to be $\sim 1$ $\mu \mathrm{M}$. One of our goals was to generate compounds with near or below $0.1 \mu \mathrm{M}$ potency against MERS-CoV and other target coronaviruses. All synthesized compounds displayed varying degrees of inhibitory activity against multiple coronaviruses in the FRET enzyme assay and cell-based assays. Among these compounds, $\boldsymbol{\sigma e}$ showed the most potent antiviral activity against SARS-CoV-2 3CLpro in a FRET enzyme assay ( $\mathrm{IC}_{50}$ $0.17 \mu \mathrm{M})$ and cell-based assays $\left(\mathrm{EC}_{50} 0.15 \mu \mathrm{M}\right)$, and $\boldsymbol{6 j}$ showed the most potent antiviral activity against MERS-CoV with an $\mathrm{EC}_{50}$ value of $0.04 \mu \mathrm{M}$ (Table 2).

It was previously demonstrated that optimal potency is attained when the $\mathrm{P}_{1}$ and $\mathrm{P}_{2}$ residues are a glutamine surrogate and Leu, respectively, and that replacement of the $\mathrm{P}_{2} \mathrm{Leu}$ with a cyclohexylalanine is inimical to potency (17-18). This is clearly evident when comparing the relative potencies of $\boldsymbol{6 h}$ and $\boldsymbol{7 h}$ versus $\boldsymbol{6 i}$ and $\boldsymbol{7 \boldsymbol { i }}$ (Table 1 and Table S1). Furthermore, compounds with Leu at the $\mathrm{P}_{2}$ position showed higher $\mathrm{CC}_{50}$ values compared to those with cyclohexylalanine at $\mathrm{P}_{2}$ (Table S1). X-ray crystallography confirmed the mechanism of action of the inhibitors, which involves formation of a covalent bond between the active site cysteine and the carbonyl carbon of the aldehyde. X-ray crystallography also identified the structural determinants associated with binding, accounting for the observed differences in potency. The high-resolution cocrystal structures of 3CLpro inhibitors $\boldsymbol{7} \boldsymbol{j}$ and $\boldsymbol{7 i}$ with MERS$\mathrm{CoV}$ 3CLpro also confirmed that the difference in activity arose from the loss of a H-bond with Gln192 and the loss of two additional H-bonds from the displacement of Gln167 and Phe143 with $\boldsymbol{7 \boldsymbol { i }}$ (Fig. S2A). The nature of the interaction of $\boldsymbol{\eta j}$ with the $\mathrm{S}_{4}$ subsite is unique among the compounds examined and provides strong support for our approach, vis-a-vis our focus on the cap position for enhancing binding affinity and potency. Compound $\boldsymbol{7 j}$ was cocrystallized with MERSCoV, SARS-CoV, and SARS-CoV-2 3CLpro. Superposition of compound $7 \boldsymbol{j}$ with these 3CLpro enzymes revealed a similar binding mode amongst all three proteases. However, a key difference lies with the different conformation adopted by the difluorocyclohexyl ring in the MERS-CoV 3CLpro $S_{4}$ subsite, enabling it to engage in additional $\mathrm{H}$-bond binding interactions (Fig. 2E and Fig S4). Compound $\boldsymbol{7 j}$ had moderately lower potency against SARS-CoV 3CLpro and SARS-CoV-2 3CLpro compared to MERS-CoV 3CLpro in the FRET enzyme assay, suggesting that moieties forming $\mathrm{H}$-bonds that were accommodated at the $\mathrm{S}_{4}$ subsite had an important impact on potency. Notably, the barrier to the development of drug resistance increases when an inhibitor engages in H-bond interactions with the backbone of the 3CLpro.

We used a robust mouse model of MERS-CoV infection (30-32) to evaluate the efficacy of compounds $\boldsymbol{6} \boldsymbol{j}$ and $\boldsymbol{6} \boldsymbol{h}$. hDPP4-KI mice expressing human dipeptidylpeptidase 4 were infected with a mouse-adapted MERS-CoV virus 
(MERS $\left.\mathrm{MA}_{\mathrm{A}} \mathrm{CoV}\right)$. The infected mice develop fatal lung disease with severe inflammation and weight loss (32). Furthermore, the lung pathology caused by $\mathrm{MERS}_{\mathrm{MA}}-\mathrm{CoV}$ infection of the hDPP4-KI mice closely resembles that of severe human MERS-CoV infection and is characterized by diffuse alveolar damage, pulmonary edema, hyaline membrane formation, and infiltration of lymphocytes into the alveolar septa (22). In the current study, we demonstrated that survival rates in this mouse model were higher with $\boldsymbol{6} \boldsymbol{j}$ treatment compared to $\boldsymbol{6} \boldsymbol{h}$ treatment (Fig. 3B). Interestingly, compounds $\boldsymbol{6} \boldsymbol{j}$ and $\boldsymbol{G h}$ share a near identical structure except for the extra methylene group present in compound $\boldsymbol{6} \boldsymbol{j}$. Compound $\boldsymbol{6} \boldsymbol{h}$ showed potent anti-3CLpro activity, whereas the antiviral activity of compound $\boldsymbol{6 h}$ in cell culture was lower than that of compound $\boldsymbol{6} \boldsymbol{j}$ (Tables 1,2), which may have been the reason for its diminished therapeutic efficacy in the mouse model (Fig. 3B).

Our findings indicate that therapeutic treatment of infected mice with compound $\boldsymbol{6} \boldsymbol{j}$ was associated with a reduction in lung viral load and lung pathology (Fig. 3). Moreover, treatment of mice with $\boldsymbol{6} \boldsymbol{j}$ at 1 dpi resulted in the survival of infected mice, whereas delaying treatment initiation until 3 dpi resulted in decreased survival. Overall, mouse survival was markedly increased only when $\boldsymbol{6} \boldsymbol{j}$ was given to mice at 1 dpi (p<0.05; Fig. 3D, E). Treatment with compound $\boldsymbol{6} \boldsymbol{j}$ starting at 2 dpi resulted in moderately increased survival of infected mice, but this was not statistically significant $(\mathrm{p}>0.05)$. These results emphasize the importance of early therapeutic intervention in attaining a positive clinical outcome.

Earlier studies from our group showed that GC376 can cure fatal feline coronavirus disease in cats $(20,21)$, demonstrating that a specific coronavirus protease inhibitor can be effective therapeutically against coronavirus disease in a natural host. The MERS-CoV mouse model used here provides proof-of-principle regarding the therapeutic potential of our protease inhibitors for treating severe human respiratory coronavirus disease. Limitations of the current study include differences in host receptor usage, mortality and transmissibility between MERS-CoV and SARS-CoV-2. Thus, further evaluation of our protease inhibitors in mice, hamsters or nonhuman primates experimentally infected with SARS-CoV2 will be crucial to assess these inhibitors as potential therapeutic options for COVID-19.

Our study showed that these compounds were broadly active against the 3CLpro of several coronaviruses, with compound $\boldsymbol{6} \boldsymbol{j}$ displaying the highest activity against MERS-CoV and compound $\boldsymbol{6} \boldsymbol{e}$ displaying the highest activity against SARS-CoV-2. Clinical efficacy is influenced by many factors, including drug bioavailability, PK, metabolism and the chemical stability of a compound. This poses a major challenge with respect to reliably predicting whether the difference in potency against different coronaviruses in assays in vitro can be translated to differences in clinical efficacy. Therefore, further research is needed to establish whether one protease inhibitor can be an effective therapeutic for both MERS-CoV and SARS-CoV-2 infections in humans. We have demonstrated that the dipeptidyl compound series can serve as a platform suitable for the structure-guided design of one or more inhibitors against highly virulent human coronaviruses. We have generated potent inhibitors of the 3CLpro of several coronaviruses, including SARS-CoV-2, and tested their efficacy in cultured cells and primary human airway epithelial cells. Furthermore, we have demonstrated proof-of-concept therapeutic efficacy for one 3CLpro inhibitor $\boldsymbol{6} \boldsymbol{j}$ in hDPP4-KI mice infected with MERS $\mathrm{MA}_{\mathrm{MA}} \mathrm{CoV}$. Our study lays the foundation for advancing this compound series further along the drug development pipeline.

\section{MATERIALS AND METHODS \\ Study Design}

The goal of this study was to evaluate the efficacy of 3CLpro inhibitors against human coronaviruses, including SARS-CoV-2, in a FRET enzyme assay and cell culture assays, as well as in a mouse model of MERS-CoV infection. Initial antiviral screening was performed with recombinant 3CLpro from SARS-CoV, MERS-CoV and SARS-CoV-2 in the FRET enzyme assay. Antiviral activity was then assessed in cultured Huh-7 cells infected with MERS-CoV and Vero E6 cells infected with SARS-CoV-2. Selected 3CLpro inhibitors were further examined using X-ray co-crystallization with MERS-CoV, SARS-CoV and SARS-CoV-2 3CLpro to elucidate the mechanism of action and identify the structural determinants of potency. Finally, two selected compounds were evaluated for in vivo efficacy in a mouse model of MERS-CoV infection (hDPP4-KI mice expressing human dipeptidylpeptidase 4 infected with a mouse-adapted MERS-CoV). Age- and sexmatched mice were randomly assigned into various groups for virus infection and treatment studies. Microscopic analysis of lung lesions was conducted in a blinded manner; other experiments were not blinded. No mice were excluded from analysis.

In vivo studies were performed in animal biosafety level 3 facilities at the University of Iowa. All experiments were conducted under protocols approved by the Institutional Animal Care and Use Committee at the University of Iowa according to guidelines set by the Association for the Assessment and Accreditation of Laboratory Animal Care and the U.S. Department of Agriculture.

The studies with MERS-CoV and SARS-CoV-2 were performed in biosafety level 3 facilities at the University of Iowa. All experiments were conducted under protocols approved by the Institutional Biosafety Committee at the University of Iowa according to guidelines set by the Biosafety in Microbiological and Biomedical Laboratories, the U.S. Department of Health and Human Services, the U.S. Public Health Service, 
the U.S. Centers for Disease Control and Prevention, and the National Institutes of Health.

\section{Synthesis of 3CL protease inhibitors}

Compounds $\mathbf{6 a}-\boldsymbol{k}$ and $\boldsymbol{7 a}-\boldsymbol{k}$ were readily synthesized as illustrated in Fig. 1 and are listed in Table 1 and Table S1. Briefly, the alcohol inputs were reacted with (L) leucine isocyanate methyl ester or (L) cyclohexylalanine isocyanate methyl ester to yield dipeptides 2 which were then hydrolyzed to the corresponding acids with lithium hydroxide in aqueous tetrahydrofuran. Subsequent coupling of the acids to glutamine surrogate methyl ester $\boldsymbol{8}(33,34)$ furnished compounds 4. Lithium borohydride reduction yielded alcohols 5 which were then oxidized to the corresponding aldehydes $\boldsymbol{6}$ with Dess-Martin periodinane reagent. The bisulfite adducts $\boldsymbol{7}$ were generated by treatment with sodium bisulfite in aqueous ethanol and ethyl acetate (35).

\section{Fluorescence resonance energy transfer (FRET) enzyme assay}

The expression and purification of the 3CLpro of MERSCoV, SARS-CoV and FIPV was performed by a standard method described previously by our lab $(11,19,20)$. We also cloned and expressed the 3CLpro of SARS-CoV-2. The codonoptimized cDNA of full length of 3CLpro of SARS-CoV-2 (GenBank number MN908947.3) fused with sequences encoding 6 histidine at the N-terminal was synthesized by Integrated DNA (Coralville, IA). The synthesized gene was subcloned into the pET-28a(+) vector. The expression and purification of SARS-CoV-2 3CLpro were conducted following a standard procedure described by our lab (19). Briefly, stock solutions of compounds $\boldsymbol{6} \boldsymbol{a}-\boldsymbol{k}$ and $\boldsymbol{7 a}-\boldsymbol{k}$ were prepared in DMSO and diluted in assay buffer, which was comprised of $20 \mathrm{mM}$ HEPES buffer, $\mathrm{pH} 8$, containing $\mathrm{NaCl}(200 \mathrm{mM})$, EDTA (0.4 $\mathrm{mM}$ ), glycerol (60\%), and $6 \mathrm{mM}$ dithiothreitol (DTT). The protease (3CLpro of MERS-CoV, SARS-CoV, SARS-CoV-2 or FIPV) was mixed with serial dilutions of each compound or with DMSO in $25 \mu \mathrm{L}$ of assay buffer and incubated at $37^{\circ} \mathrm{C}$ for $30 \mathrm{~min}$ (MERS-CoV and FIPV) or at room temperature for 1 hour (SARS-CoV and SARS-CoV-2), followed by the addition of $25 \mu \mathrm{L}$ of assay buffer containing substrate (FAMSAVLQ/SG-QXL ${ }^{\circledR} 520$, AnaSpec, Fremont, CA). The substrate was derived from the cleavage sites on the viral polyproteins of SARS-CoV. Fluorescence readings were obtained using an excitation wavelength of $480 \mathrm{~nm}$ and an emission wavelength of $520 \mathrm{~nm}$ on a fluorescence microplate reader (FLx800; Biotec, Winoosk, VT) 1 hour following the addition of substrate. Relative fluorescence units (RFU) were determined by subtracting background values (substrate-containing well without protease) from the raw fluorescence values, as described previously (19). The dose-dependent FRET inhibition curves were fitted with a variable slope by using GraphPad Prism software (GraphPad, La Jolla, CA) in order to determine the $\mathrm{IC}_{50}$ values of the compounds.

\section{Antiviral cell-based assays}

Some compounds in $\mathbf{6 a}-\boldsymbol{k}$ and $\boldsymbol{7 a}-\boldsymbol{k}$ series were also investigated for their antiviral activity against the replication of MERS-CoV, FIPV or MHV-1 in Huh-7, CRFK or CCL1 cells, respectively (19). Briefly, medium containing DMSO $(<0.1 \%)$ or each compound (up to $100 \mu \mathrm{M}$ ) was added to confluent cells, which were immediately infected with viruses at an MOI of 0.01 . After incubation of the cells at $37^{\circ} \mathrm{C}$ for 24 hours, viral titers were determined with the TCID $_{50}$ method (FIPV or MHV) with the CRFK or CLL1 cells or plaque assay with Vero81 cells (MERS-CoV). For SARS-CoV-2, confluent VeroE6 cells were inoculated with $\sim 50-100$ plaque forming units/well, and medium containing various concentrations of each compound and agar was applied to the cells. After 48-72 hours, plaques in each well were counted. $\mathrm{EC}_{50}$ values were determined by GraphPad Prism software using a variable slope (GraphPad, La Jolla, CA) (19). To confirm that these inhibitors also inhibit SARS-CoV-2 in primary human cells, differentiated human airway epithelial cells from 3 donors were used as previously described $(36,37)$. Two compounds $(\boldsymbol{6} \boldsymbol{j}$ and $\boldsymbol{6 e})$ were tested for their antiviral effects against SARS-CoV2. Briefly, airway epithelial cells were washed with PBS and SARS-CoV2 was inoculated at a MOI of 0.1 for 1 hour. After the inoculum was removed, media containing $\boldsymbol{6} \boldsymbol{j}(2 \mu \mathrm{M})$ or $\boldsymbol{6} \boldsymbol{e}$ $(0.5 \mu \mathrm{M})$ was added. After 48 hours, cells were subjected to a freeze/thaw cycle, and virus titers were determined by plaque assay on Vero E6 cells.

\section{Measurement of cytotoxicity}

The cytotoxic dose for $50 \%$ cell death $\left(\mathrm{CC}_{50}\right)$ for compounds $\boldsymbol{6 a}-\boldsymbol{k}$ and $\boldsymbol{7 a}-\boldsymbol{k}$ was determined in Huh-7, CRFK or CCL1 cells. Confluent cells grown in 96-well plates were incubated with various concentrations ( 1 to $100 \mu \mathrm{M}$ ) of each compound for 72 hours. Cell cytotoxicity was measured by a CytoTox 96 nonradioactive cytotoxicity assay kit (Promega, Madison, WI), and the $\mathrm{CC}_{50}$ values were calculated using a variable slope by GraphPad Prism software. The in vitro therapeutic index was calculated by dividing the $\mathrm{CC}_{50}$ by the $\mathrm{EC}_{50}$.

Protein purification, crystallization and data collection in X-ray crystallographic studies

MERS-CoV 3CLpro and SARS-CoV 3CLpro were purified as described previously $(17,19)$. An $E$. coli codon optimized construct encoding residues Ser 3264 to Phe 3568 of the orflab polyprotein (SARS-CoV-2 3CLpro, Genebank QHD43415.1) was cloned into a pET His6 Sumo TEV LIC cloning vector (2S-T, addgene). Expression and initial Ni-column purification was performed as described for MERS-CoV 3CLpro and SARS-CoV 3CLpro. The SUMO fusion elution fractions of SARS-CoV-2 were dialyzed against $20 \mathrm{mM}$ Tris $\mathrm{pH}$ $8.0,100 \mathrm{mM} \mathrm{NaCl}$ and treated with TEV protease $(1: 10 \mathrm{w} / \mathrm{w})$ overnight. This mixture was loaded onto $5 \mathrm{~mL}$ HisTrap HP column (GE Healthcare) equilibrated with $20 \mathrm{mM}$ Tris $\mathrm{pH}$ 8.0, $100 \mathrm{mM} \mathrm{NaCl}$ and eluted with $20 \mathrm{mM}$ Tris $\mathrm{pH} 8.0,100$ 
$\mathrm{mM} \mathrm{NaCl}, 500 \mathrm{mM}$ imidazole using an AKTA Pure FPLC. The flow through fractions, containing SARS-CoV-2 3CLpro without the SUMO fusion loaded onto a Superdex 75 10/300 GL size-exclusion column equilibrated with $20 \mathrm{mM}$ Tris $\mathrm{pH}$ 8.0, $100 \mathrm{mM} \mathrm{NaCl}$. The fractions were pooled and concentrated to $9.6 \mathrm{mg} / \mathrm{mL}$ for crystallization screening. Note that four residues from cloning (SNIG) remain at the $\mathrm{N}$ terminus following treatment with TEV protease.

Purified MERS-CoV 3CLpro, SARS-CoV 3CLpro and SARSCoV-2 3CLpro in $100 \mathrm{mM} \mathrm{NaCl}, 20 \mathrm{mM}$ Tris pH 8.0 were concentrated to $10.6 \mathrm{mg} / \mathrm{mL}(0.3 \mathrm{mM}), 22 \mathrm{mg} / \mathrm{mL}(0.64 \mathrm{mM})$ and $9.6 \mathrm{mg} / \mathrm{mL}(0.28 \mathrm{mM})$ respectively for crystallization screening. All crystallization experiments were setup using an NT8 drop-setting robot (Formulatrix Inc.) and UVXPO MRC (Molecular Dimensions) sitting drop vapor diffusion plates at $18^{\circ} \mathrm{C} .100 \mathrm{~nL}$ of protein and $100 \mathrm{~nL}$ crystallization solution were dispensed and equilibrated against $50 \mu \mathrm{L}$ of the latter. Stock solutions (100 mM) of compounds $\boldsymbol{6 b}, \boldsymbol{6 d}, \boldsymbol{6} \mathbf{g}, \boldsymbol{6 h}, \boldsymbol{7 i}$, and $\boldsymbol{z} \boldsymbol{j}$ were prepared in DMSO and complexes were generated by mixing $1 \mu \mathrm{L}$ of the ligand $(2 \mathrm{mM})$ with $49 \mu \mathrm{L}(0.29$ $\mathrm{mM}$ ) of the protease and incubating on ice for 1 hour. Crystals of the MERS-CoV 3CLpro inhibitor complexes were obtained from the following conditions. Compounds $6 \boldsymbol{b}, \boldsymbol{6 d}, \boldsymbol{6} \boldsymbol{g}$ and 6h: Proplex screen (Molecular Dimensions) condition E2 (8\% (w/v) PEG 8000, $100 \mathrm{mM}$ sodium citrate $\mathrm{pH}$ 5.0), compound 7i: Proplex screen (Molecular Dimensions) condition B8 (15\% (w/v) PEG 4000, $100 \mathrm{mM}$ sodium citrate $\mathrm{pH}$ 5.0, $100 \mathrm{mM}$ magnesium chloride) and compound $7 \mathbf{j}$ : Index HT screen (Hampton Research) condition F6 (25\% (w/v) PEG 3350, 100 $\mathrm{mM}$ Bis-Tris pH 5.5, $200 \mathrm{mM}$ ammonium sulfate). Crystals of the SARS-CoV 3CLpro complex with compound $\boldsymbol{z} \boldsymbol{j}$ were obtained from the Index HT screen (Hampton Research) condition H8 (15\% (w/v) PEG 3350, $100 \mathrm{mM}$ magnesium formate). Crystals of the SARS-CoV-2 3CLpro complex with compound $\boldsymbol{7 j}$ were obtained in 1-2 days from the PACT HT screen (Molecular Dimensions) condition D7 (20\% (w/v) PEG 6000, 100 $\mathrm{mM}$ Tris $\mathrm{pH}$ 8.0, $200 \mathrm{mM} \mathrm{NaCl})$. Samples were transferred to a fresh drop containing $80 \%$ crystallant and $20 \%$ (v/v) PEG 200 before storing in liquid nitrogen. X-ray diffraction data were collected at the Advanced Photon Source beamline 17ID using a Dectris Pilatus 6M (MERS-CoV 3CLpro and SARSCoV 3CLpro) and Dectris Eiger2 X 9M (SARS-CoV-2 3CLpro) pixel array detector.

\section{Solution and refinement of crystal structures}

Intensities were integrated using XDS $(38,39)$ using Autoproc $(40)$ and the Laue class analysis and data scaling were performed with Aimless (41). Structure solution was conducted by molecular replacement with Phaser (42) using a previously determined structure of MERS 3CLpro (PDB: 5WKK (17)) and SARS-CoV 3CLpro (PDB: 1Q2W (43)) SARSCoV-2 3CLpro (PDB: 6LU7 (44)) as the search models. Structure refinement and manual model building were conducted with Phenix (45) and Coot (46), respectively. Disordered side chains were truncated to the point for which electron density could be observed. Structure validation was conducted with MolProbity (47) and figures were prepared using the CCP4MG package (48). Crystallographic data are provided in Table S2.

\section{Therapeutic treatment in a mouse model of MERS-CoV infection}

The two best compounds ( $\boldsymbol{6} \boldsymbol{j}$ and $\boldsymbol{6 h})$ in the series were examined for their in vivo efficacy using 10 -week old male

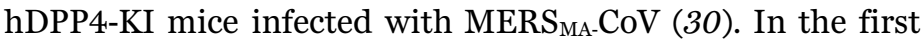
study, animals were divided into three groups $(n=5-6)$ and were lightly anesthetized with ketamine/xylazine and infected with $50 \mu \mathrm{l}$ of $750 \mathrm{pfu} \mathrm{MERS}_{\mathrm{MA}}-\mathrm{CoV}$ via intranasal inoculation. Compounds $\boldsymbol{6} \boldsymbol{j}$ or $\boldsymbol{6 h}$ were formulated in $10 \%$ ethanol and 90\% PEG400 and given to mice from 1 to 10 dpi at 50 $\mathrm{mg} / \mathrm{kg} /$ day (once per day) via intraperitoneal administration. The control mice received vehicle. Animals were weighed daily and monitored for 15 days. Animals were euthanized when an animal lost $30 \%$ of initial weight or at $15 \mathrm{dpi}$.

In the next study, treatment with compound $\boldsymbol{6} \boldsymbol{j}$ was delayed up to 3 dpi to determine the impact of delayed treatment on mouse survival. Animals were divided into five groups ( $\mathrm{n}=5)$ and compound $\boldsymbol{6} \boldsymbol{j}(50 \mathrm{mg} / \mathrm{kg} /$ day, once per day) was administered to mice starting at one, two or three days after virus challenge (1, 2 or $3 \mathrm{dpi}$, respectively) until $10 \mathrm{dpi}$. Mice were monitored for weight loss and survival as described above for 15 days post virus challenge. As controls, vehicle (10\% ethanol+90\% PEG400) was administered equivalently to the experimental compound or animals received no treatment (untreated). The third study was conducted to assess the effects of therapeutic treatment of compound $\boldsymbol{6} \boldsymbol{j}$ in the lungs. For lung harvest and virus titration, animals were divided into three groups $(n=4)$ of mice and compound $\boldsymbol{6} \boldsymbol{j}$ (50 $\mathrm{mg} / \mathrm{kg} /$ day, once per day) or vehicle was administered to mice starting at 1 dpi until euthanasia. Animals were euthanized at 3 or $5 \mathrm{dpi}$, and lungs were removed aseptically, disassociated with a manual homogenizer in 1x PBS, briefly centrifuged, and supernatants removed. Samples were titered on Vero-81 cells as reported elsewhere (49). For lung histopathology analyses, animals were divided into two groups $(\mathrm{n}=5)$ and compound $\boldsymbol{6} \boldsymbol{j}(50 \mathrm{mg} / \mathrm{kg} /$ day, once per day) or vehicle was administered to mice starting at 1 dpi for 5 days. Mice were euthanized at $6 \mathrm{dpi}$, lungs were fixed with $10 \%$ formalin, and hematoxylin and eosin stained tissues were examined by a veterinary pathologist using the post-examination method of masking (50). Briefly, tissues were scored in an ordinal manner for edema and hyaline membrane formation using the following scale: 0 , none; 1 , rare ( $<5$ alveoli); $2,<33 \%$ of lung fields; $3,34-66 \%$ lung fields, and $4,>66 \%$ lung fields (30). 


\section{Statistical analysis}

The analysis of survival curves in groups was performed using a Log-rank (Mantel-Cox) test and Gehan-Breslow-Wilcoxon test using GraphPad Prism Software (San Diego, CA). Log-transformed viral titers in the lungs, and lung edema and hyaline membrane formation in groups of mice were analyzed with multiple $t$ tests using GraphPad Prism Software.

\section{SUPPLEMENTARY MATERIALS}

stm.sciencemag.org/cgi/content/full/scitranslmed.abc5332/DC1

Fig. S1. X-ray cocrystal structures of compounds with coronavirus 3CLpro showing the Fo-Fc omit map.

Fig. S2. X-ray cocrystal structures of compounds with coronavirus 3CLpro showing hydrogen bond interactions.

Fig. S3. X-ray cocrystal structures of compounds with coronavirus 3CLpro showing electrostatic surface representation.

Fig. S4. X-ray cocrystal structures of comparative binding of $7 \mathrm{j}$ with the 3CLpro of MERS COV, SARS-CoV and SARS-CoV-2.

Table S1. Compound $\mathrm{IC}_{50}$ in the FRET enzyme assay and $\mathrm{CC}_{50}$ in a cell culture assay for MERS-CoV 3CLpro

Table S2. Cocrystal structure data for compounds with the 3CLpro of MERS CoV and SARS COV

References (51-56)

Data File S1. Individual-level data for all figures and tables.

\section{REFERENCES AND NOTES}

1. K. V. Homes, Ed., Coronaviruses, (Lippincott Williams \& Wilkins, Philadelphia, 2001), pp. 1187-1203.

2. R. Lu, X. Zhao, J. Li, P. Niu, B. Yang, H. Wu, W. Wang, H. Song, B. Huang, N. Zhu, Y. Bi, X. Ma, F. Zhan, L. Wang, T. Hu, H. Zhou, Z. Hu, W. Zhou, L. Zhao, J. Chen, Y. Meng, J. Wang, Y. Lin, J. Yuan, Z. Xie, J. Ma, W. J. Liu, D. Wang, W. Xu, E. C. Holmes, G. F. Gao, G. Wu, W. Chen, W. Shi, W. Tan, Genomic characterisation and epidemiology of 2019 novel coronavirus: Implications for virus origins and receptor binding. Lancet 395, 565-574 (2020). doi:10.1016/S01406736(20)30251-8 Medline

3. A. Zumla, J. F. Chan, E. I. Azhar, D. S. Hui, K. Y. Yuen, Coronaviruses - drug discovery and therapeutic options. Nat. Rev. Drug Discov. 15, 327-347 (2016). doi:10.1038/nrd.2015.37 Medline

4. A. L. Totura, S. Bavari, Broad-spectrum coronavirus antiviral drug discovery. Expert Opin. Drug Discov. 14, 397-412 (2019). doi:10.1080/17460441.2019.1581171 Medline

5. S. Skariyachan, S. B. Challapilli, S. Packirisamy, S. T. Kumargowda, V. S. Sridhar, Recent Aspects on the Pathogenesis Mechanism, Animal Models and Novel Therapeutic Interventions for Middle East Respiratory Syndrome Coronavirus Infections. Front. Microbiol. 10, 569 (2019). doi:10.3389/fmicb.2019.00569 Medline

6. J. Dyall, R. Gross, J. Kindrachuk, R. F. Johnson, G. G. Olinger Jr., L. E. Hensley, M. B. Frieman, P. B. Jahrling, Middle East Respiratory Syndrome and Severe Acute Respiratory Syndrome: Current Therapeutic Options and Potential Targets for Novel Therapies. Drugs 77, 1935-1966 (2017). doi:10.1007/s40265-017-0830-1 Medline

7. L. Zhang, D. Lin, X. Sun, U. Curth, C. Drosten, L. Sauerhering, S. Becker, K. Rox, R. Hilgenfeld, Crystal structure of SARS-CoV-2 main protease provides a basis for design of improved $\alpha$-ketoamide inhibitors. Science 368, 409-412 (2020). Medline

8. D. Needle, G. T. Lountos, D. S. Waugh, Structures of the Middle East respiratory syndrome coronavirus 3C-like protease reveal insights into substrate specificity. Acta Crystallogr. D Biol. Crystallogr. 71, 1102-1111 (2015). doi:10.1107/S1399004715003521 Medline

9. R. Hilgenfeld, From SARS to MERS: Crystallographic studies on coronaviral proteases enable antiviral drug design. FEBS J. 281, 4085-4096 (2014). doi:10.1111/febs.12936 Medline
10. A. Wu, Y. Wang, C. Zeng, X. Huang, S. Xu, C. Su, M. Wang, Y. Chen, D. Guo, Prediction and biochemical analysis of putative cleavage sites of the $3 \mathrm{C}$-like protease of Middle East respiratory syndrome coronavirus. Virus Res. 208, 56-65 (2015). doi:10.1016/j.virusres.2015.05.018 Medline

11. Y. Kim, V. Shivanna, S. Narayanan, A. M. Prior, S. Weerasekara, D. H. Hua, A. C. Kankanamalage, W. C. Groutas, K. O. Chang, Broad-spectrum inhibitors against 3C-like proteases of feline coronaviruses and feline caliciviruses. J. Virol. 89, 4942-4950 (2015). doj:10.1128/JVL.03688-14 Medline

12. S. R. Mandadapu, M. R. Gunnam, K. C. Tiew, R. A. Uy, A. M. Prior, K. R. Alliston, D. H. Hua, Y. Kim, K. O. Chang, W. C. Groutas, Inhibition of norovirus 3CL protease by bisulfite adducts of transition state inhibitors. Bioorg. Med. Chem. Lett. 23, 62-65 (2013). doi:10.1016/i.bmcl.2012.11.026 Medline

13. Y. Kim, S. R. Mandadapu, W. C. Groutas, K. O. Chang, Potent inhibition of feline coronaviruses with peptidyl compounds targeting coronavirus 3C-like protease. Antiviral Res. 97, 161-168 (2013). doi:10.1016/j.antiviral.2012.11.005 Medline

14. S. R. Mandadapu, P. M. Weerawarna, M. R. Gunnam, K. R. Alliston, G. H. Lushington, Y. Kim, K. O. Chang, W. C. Groutas, Potent inhibition of norovirus 3CL protease by peptidyl $\alpha$-ketoamides and $\alpha$-ketoheterocycles. Bioorg. Med. Chem. Lett. 22, 4820-4826 (2012). doi:10.1016/j.bmcl.2012.05.055 Medline

15. A. C. Galasiti Kankanamalage, Y. Kim, P. M. Weerawarna, R. A. Uy, V. C. Damalanka, S. R. Mandadapu, K. R. Alliston, N. Mehzabeen, K. P. Battaile, S. Lovell, K. O. Chang, W. C. Groutas, Structure-guided design and optimization of dipeptidyl inhibitors of norovirus $3 \mathrm{CL}$ protease. Structure-activity relationships and biochemical, X-ray crystallographic, cell-based, and in vivo studies. J. Med. Chem. 58, 3144-3155 (2015). doi:10.1021/jm5019934 Medline

16. A. C. Galasiti Kankanamalage, Y. Kim, A. D. Rathnayake, V. C. Damalanka, P. M. Weerawarna, S. T. Doyle, A. F. Alsoudi, D. M. P. Dissanayake, G. H. Lushington, N. Mehzabeen, K. P. Battaile, S. Lovell, K. O. Chang, W. C. Groutas, Structure-based exploration and exploitation of the $\mathrm{S}_{4}$ subsite of norovirus $3 \mathrm{CL}$ protease in the design of potent and permeable inhibitors. Eur. J. Med. Chem. 126, 502-516 (2017). doi:10.1016/j.ejmech.2016.11.027 Medline

17. A. C. Galasiti Kankanamalage, Y. Kim, V. C. Damalanka, A. D. Rathnayake, A. R. Fehr, N. Mehzabeen, K. P. Battaile, S. Lovell, G. H. Lushington, S. Perlman, K. O. Chang, W. C. Groutas, Structure-guided design of potent and permeable inhibitors of MERS coronavirus 3CL protease that utilize a piperidine moiety as a novel design element. Eur. J. Med. Chem. 150, 334-346 (2018). doi:10.1016/i.ejmech.2018.03.004 Medline

18. K. D. Perera, A. C. Galasiti Kankanamalage, A. D. Rathnayake, A. Honeyfield, W. Groutas, K. O. Chang, Y. Kim, Protease inhibitors broadly effective against feline, ferret and mink coronaviruses. Antiviral Res. 160, 79-86 (2018). doi:10.1016/j.antiviral.2018.10.015 Medline

19. Y. Kim, S. Lovell, K. C. Tiew, S. R. Mandadapu, K. R. Alliston, K. P. Battaile, W. C. Groutas, K. O. Chang, Broad-spectrum antivirals against $3 \mathrm{C}$ or $3 \mathrm{C}$-like proteases of picornaviruses, noroviruses, and coronaviruses. J. Virol. 86, 11754-11762 (2012). doi:10.1128/JVL.01348-12 Medline

20. Y. Kim, H. Liu, A. C. Galasiti Kankanamalage, S. Weerasekara, D. H. Hua, W. C. Groutas, K. O. Chang, N. C. Pedersen, Reversal of the Progression of Fatal Coronavirus Infection in Cats by a Broad-Spectrum Coronavirus Protease Inhibitor. PLOS Pathog. 12, e1005531 (2016). doi:10.1371/journal.ppat.1005531 Medline

21. N. C. Pedersen, Y. Kim, H. Liu, A. C. Galasiti Kankanamalage, C. Eckstrand, W. C. Groutas, M. Bannasch, J. M. Meadows, K. O. Chang, Efficacy of a 3C-like protease inhibitor in treating various forms of acquired feline infectious peritonitis. J. Feline Med. Surg. 20, 378-392 (2018). doi:10.1177/1098612X17729626 Medline

22. D. L. Ng, F. Al Hosani, M. K. Keating, S. I. Gerber, T. L. Jones, M. G. Metcalfe, S. Tong, Y. Tao, N. N. Alami, L. M. Haynes, M. A. Mutei, L. Abdel-Wareth, T. M. Uyeki, D. L. Swerdlow, M. Barakat, S. R. Zaki, Clinicopathologic, Immunohistochemical, and Ultrastructural Findings of a Fatal Case of Middle East Respiratory Syndrome Coronavirus Infection in the United Arab Emirates, April 2014. Am. J. Pathol. 186, 652-658 (2016). doi:10.1016/j.ajpath.2015.10.024 Medline

23. T. P. Sheahan, A. C. Sims, S. R. Leist, A. Schäfer, J. Won, A. J. Brown, S. A. Montgomery, A. Hogg, D. Babusis, M. O. Clarke, J. E. Spahn, L. Bauer, S. Sellers, D. Porter, J. Y. Feng, T. Cihlar, R. Jordan, M. R. Denison, R. S. Baric, Comparative therapeutic efficacy of remdesivir and combination lopinavir, ritonavir, and interferon beta against MERS-CoV. Nat. Commun. 11, 222 (2020). 
doi:10.1038/s41467-019-13940-6 Medline

24. E. de Wit, F. Feldmann, J. Cronin, R. Jordan, A. Okumura, T. Thomas, D. Scott, T. Cihlar, H. Feldmann, Prophylactic and therapeutic remdesivir (GS-5734) treatment in the rhesus macaque model of MERS-CoV infection. Proc. Natl. Acad. Sci. U.S.A. 117, 6771-6776 (2020). doi:10.1073/pnas.1922083117 Medline

25. T. K. Warren, R. Jordan, M. K. Lo, A. S. Ray, R. L. Mackman, V. Soloveva, D. Siegel, M. Perron, R. Bannister, H. C. Hui, N. Larson, R. Strickley, J. Wells, K. S. Stuthman, S. A. Van Tongeren, N. L. Garza, G. Donnelly, A. C. Shurtleff, C. J. Retterer, D. Gharaibeh, R. Zamani, T. Kenny, B. P. Eaton, E. Grimes, L. S. Welch, L. Gomba, C. L. Wilhelmsen, D. K. Nichols, J. E. Nuss, E. R. Nagle, J. R. Kugelman, G. Palacios, E. Doerffler, S. Neville, E. Carra, M. O. Clarke, L. Zhang, W. Lew, B. Ross, Q. Wang, K Chun, L. Wolfe, D. Babusis, Y. Park, K. M. Stray, I. Trancheva, J. Y. Feng, O. Barauskas, Y. Xu, P. Wong, M. R. Braun, M. Flint, L. K. McMullan, S. S. Chen, R. Fearns, S. Swaminathan, D. L. Mayers, C. F. Spiropoulou, W. A. Lee, S. T. Nichol, T. Cihlar, S. Bavari, Therapeutic efficacy of the small molecule GS-5734 against Ebola virus in rhesus monkeys. Nature 531, 381-385 (2016). doi:10.1038/nature17180 Medline

26. T. P. Sheahan, A. C. Sims, R. L. Graham, V. D. Menachery, L. E. Gralinski, J. B. Case, S. R. Leist, K. Pyrc, J. Y. Feng, I. Trantcheva, R. Bannister, Y. Park, D. Babusis, M. O. Clarke, R. L. Mackman, J. E. Spahn, C. A. Palmiotti, D. Siegel, A. S. Ray, T. Cihlar, R. Jordan, M. R. Denison, R. S. Baric, Broad-spectrum antiviral GS-5734 inhibits both epidemic and zoonotic coronaviruses. Sci. Transl. Med. 9, eaal3653 (2017). doi:10.1126/scitranslmed.aal3653 Medline

27. V. J. Munster, F. Feldmann, B. N. Williamson, N. van Doremalen, L. Pérez-Pérez, J. Schulz, K. Meade-White, A. Okumura, J. Callison, B. Brumbaugh, V. A. Avanzato, R. Rosenke, P. W. Hanley, G. Saturday, D. Scott, E. R. Fischer, E. de Wit Respiratory disease in rhesus macaques inoculated with SARS-CoV-2. Nature (2020). doi:10.1038/s41586-020-2324-7 Medline

28. T. P. Sheahan, A. C. Sims, S. Zhou, R. L. Graham, A. J. Pruijssers, M. L. Agostini, S. R. Leist, A. Schäfer, K. H. Dinnon 3rd, L. J. Stevens, J. D. Chappell, X. Lu, T. M. Hughes, A. S. George, C. S. Hill, S. A. Montgomery, A. J. Brown, G. R. Bluemling, M. G. Natchus, M. Saindane, A. A. Kolykhalov, G. Painter, J. Harcourt, A. Tamin, N. J. Thornburg, R. Swanstrom, M. R. Denison, R. S. Baric, An orally bioavailable broadspectrum antiviral inhibits SARS-CoV-2 in human airway epithelial cell cultures and multiple coronaviruses in mice. Sci. Transl. Med. 12, eabb5883 (2020). doi:10.1126/scitransImed.abb5883 Medline

29. A. M. Prior, Y. Kim, S. Weerasekara, M. Moroze, K. R. Alliston, R. A. Uy, W. C. Groutas, K. O. Chang, D. H. Hua, Design, synthesis, and bioevaluation of viral $3 \mathrm{C}$ and 3C-like protease inhibitors. Bioorg. Med. Chem. Lett. 23, 6317-6320 (2013). doi:10.1016/i.bmcl.2013.09.070 Medline

30. K. Li, C. Wohlford-Lenane, S. Perlman, J. Zhao, A. K. Jewell, L. R. Reznikov, K. N. Gibson-Corley, D. K. Meyerholz, P. B. McCray Jr., Middle East Respiratory Syndrome Coronavirus Causes Multiple Organ Damage and Lethal Disease in Mice Transgenic for Human Dipeptidyl Peptidase 4. J. Infect. Dis. 213, 712-722 (2016). Medline

31. A. S. Agrawal, T. Garron, X. Tao, B. H. Peng, M. Wakamiya, T. S. Chan, R. B. Couch, C. T. Tseng, Generation of a transgenic mouse model of Middle East respiratory syndrome coronavirus infection and disease. J. Virol. 89, 3659-3670 (2015). doi:10.1128/JVI.03427-14 Medline

32. K. Li, C. L. Wohlford-Lenane, R. Channappanavar, J. E. Park, J. T. Earnest, T. B. Bair, A. M. Bates, K. A. Brogden, H. A. Flaherty, T. Gallagher, D. K. Meyerholz, S. Perlman, P. B. McCray Jr., Mouse-adapted MERS coronavirus causes lethal lung disease in human DPP4 knockin mice. Proc. Natl. Acad. Sci. U.S.A. 114, E3119E3128 (2017). doi:10.1073/pnas.1619109114 Medline

33. P. S. Dragovich, T. J. Prins, R. Zhou, S. E. Webber, J. T. Marakovits, S. A. Fuhrman, A. K. Patick, D. A. Matthews, C. A. Lee, C. E. Ford, B. J. Burke, P. A. Rejto, T. F. Hendrickson, T. Tuntland, E. L. Brown, J. W. Meador 3rd, R. A. Ferre, J. E. Harr, M. B. Kosa, S. T. Worland, Structure-based design, synthesis, and biological evaluation of irreversible human rhinovirus $3 \mathrm{C}$ protease inhibitors. 4. Incorporation of P1 lactam moieties as L-glutamine replacements. J. Med. Chem. 42, 1213-1224 (1999). doi:10.1021/im9805384 Medline

34. Q. P. Tian, N. K. Nayyar, S. Babu, L. J. Chen, J. H. Tao, S. Lee, A. Tibbetts, T. Moran, J. Liou, M. Guo, T. P. Kennedy, An efficient synthesis of a key intermediate for the preparation of the rhinovirus protease inhibitor AG7088 via asymmetric dianionic cyanomethylation of N-Boc-L-(+)-glutamic acid dimethyl ester. Tetrahedron Lett.
42, 6807-6809 (2001). doi:10.1016/S0040-4039(01)01416-2

35. D. P. Kjell, B. J. Slattery, M. J. Semo, A novel, nonaqueous method for regeneration of aldehydes from bisulfite adducts. J. Org. Chem. 64, 5722-5724 (1999). doi:10.1021/j0990543v Medline

36. P. H. Karp, T. O. Moninger, S. P. Weber, T. S. Nesselhauf, J. L. Launspach, J. Zabner, M. J. Welsh, An in vitro model of differentiated human airway epithelia. Methods for establishing primary cultures. Methods Mol. Biol. 188, 115-137 (2002). doi:10.1385/1-59259-185-X:115 Medline

37. H. P. Jia, D. C. Look, L. Shi, M. Hickey, L. Pewe, J. Netland, M. Farzan, C. WohlfordLenane, S. Perlman, P. B. McCray Jr., ACE2 receptor expression and severe acute respiratory syndrome coronavirus infection depend on differentiation of human airway epithelia. J. Virol. 79, 14614-14621 (2005). doi:10.1128/JVL.79.23.14614$\underline{14621.2005}$ Medline

38. W. Kabsch, Xds. Acta Crystallogr. D Biol. Crystallogr. 66, 125-132 (2010). doi:10.1107/S0907444909047337 Medline

39. W. Kabsch, Automatic indexing of rotation diffraction patterns. J. Appl. Cryst. 21. 67-72 (1988). doi:10.1107/S0021889887009737

40. C. Vonrhein, C. Flensburg, P. Keller, A. Sharff, O. Smart, W. Paciorek, T. Womack, G. Bricogne, Data processing and analysis with the autoPROC toolbox. Acta Crystallogr. D Struct. Biol. 67, 293-302 (2011). doi:10.1107/S0907444911007773 Medline

41. P. R. Evans, An introduction to data reduction: Space-group determination, scaling and intensity statistics. Acta Crystallogr. D Biol. Crystallogr. 67, 282-292 (2011). doi:10.1107/S090744491003982X Medline

42. A. J. McCoy, R. W. Grosse-Kunstleve, P. D. Adams, M. D. Winn, L. C. Storoni, R. J. Read, Phaser crystallographic software. J. Appl. Cryst. 40, 658-674 (2007). doi:10.1107/S0021889807021206 Medline

43. J. B. Bonanno, R. Fowler, S. Gupta, J. Hendle, D. Lorimer, R. Romero, J. M. Sauder, C. L. Wei, E. T. Liu, S. K. Burley, T. Harris, in N Y Times Web. (2003), pp. C2-C2.

44. N. Zhu, D. Zhang, W. Wang, X. Li, B. Yang, J. Song, X. Zhao, B. Huang, W. Shi, R. Lu, P. Niu, F. Zhan, X. Ma, D. Wang, W. Xu, G. Wu, G. F. Gao, W. Tan; China Novel Coronavirus Investigating and Research Team, A Novel Coronavirus from Patients with Pneumonia in China, 2019. N. Engl. J. Med. 382, 727-733 (2020). doi:10.1056/NEJMoa2001017 Medline

45. P. V. Afonine, R. W. Grosse-Kunstleve, N. Echols, J. J. Headd, N. W. Moriarty, M. Mustyakimov, T. C. Terwilliger, A. Urzhumtsev, P. H. Zwart, P. D. Adams, Towards automated crystallographic structure refinement with phenix.refine. Acta

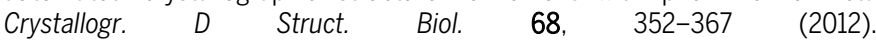
doi:10.1107/S0907444912001308 Medline

46. P. Emsley, B. Lohkamp, W. G. Scott, K. Cowtan, Features and development of Coot. Acta Crystallogr. D Biol. Crystallogr. 66, 486-501 (2010). doi:10.1107/S0907444910007493 Medline

47. V. B. Chen, W. B. Arendall 3rd, J. J. Headd, D. A. Keedy, R. M. Immormino, G. J. Kapral, L. W. Murray, J. S. Richardson, D. C. Richardson, MolProbity: All-atom structure validation for macromolecular crystallography. Acta Crystallogr. D Biol. Crystallogr. 66, 12-21 (2010). doi:10.1107/S0907444909042073 Medline

48. L. Potterton, S. McNicholas, E. Krissinel, J. Gruber, K. Cowtan, P. Emsley, G. N. Murshudov, S. Cohen, A. Perrakis, M. Noble, Developments in the CCP4 molecular-graphics project. Acta Crystallogr. D Struct. Biol. 60, 2288-2294 (2004). doi:10.1107/S0907444904023716 Medline

49. J. Zhao, K. Li, C. Wohlford-Lenane, S. S. Agnihothram, C. Fett, J. Zhao, M. J. Gale Jr., R. S. Baric, L. Enjuanes, T. Gallagher, P. B. McCray Jr., S. Perlman, Rapid generation of a mouse model for Middle East respiratory syndrome. Proc. Natl. Acad. Sci. U.S.A. 111, 4970-4975 (2014). doi:10.1073/pnas.1323279111 Medline

50. D. K. Meyerholz, A. P. Beck, Principles and approaches for reproducible scoring of tissue stains in research. Lab. Invest. 98, 844-855 (2018). doi:10.1038/s41374018-0057-0 Medline

51. P. R. Evans, An introduction to data reduction: Space-group determination, scaling and intensity statistics. Acta Crystallogr. D Biol. Crystallogr. 67, 282-292 (2011) doi:10.1107/S090744491003982X Medline

52. P. Evans, Scaling and assessment of data quality. Acta Crystallogr. D Biol. Crystallogr. 62, 72-82 (2006). doi:10.1107/S0907444905036693 Medline

53. K. Diederichs, P. A. Karplus, Improved R-factors for diffraction data analysis in macromolecular crystallography. Nat. Struct. Biol. 4, 269-275 (1997). doi:10.1038/nsb0497-269 Medline 
54. M. S. Weiss, Global indicators of X-ray data quality. J. Appl. Cryst. 34, 130-135 (2001). doi:10.1107/S0021889800018227

55. P. Evans, Biochemistry. Resolving some old problems in protein crystallography. Science 336, 986-987 (2012). doi:10.1126/science.1222162 Medline

56. P. A. Karplus, K. Diederichs, Linking crystallographic model and data quality. Science 336, 1030-1033 (2012). doi:10.1126/science.1218231 Medline

Acknowledgments: The authors thank David George for technical assistance. Funding: This research was supported in part by grants from the National Institutes of Health (NIH) (R01 Al109039 to K.O.C. and P01 Al060699 and R01 Al129269 to S. P.). Use of the University of Kansas Protein Structure Laboratory was supported by a grant from the National Institute of General Medical Sciences (P30GM110761) of the NIH. Use of the IMCA-CAT beamline 17-ID at the Advanced Photon Source was supported by the companies of the Industrial Macromolecular Crystallography Association through a contract with Hauptman-Woodward Medical Research Institute. Use of the Advanced Photon Source was supported by the U.S. Department of Energy, Office of Science, Office of Basic Energy Sciences under contract no. DE-AC02-06CH11357. Author contributions: KOC, YK, SP, WCG conceptualized the study; WCG designed the compound series optimization; ADR executed compound synthesis; SP designed cell culture and animal studies; JZ and SM investigated cell culture assays with MERS-CoV and SARS-CoV2, respectively; JZ executed animal studies with selected compounds, and KDP performed histopathology; SL designed X-ray cocrystallography studies and analysis; SL, MMK and KPB performed $X$-ray cocrystallography. KOC and YK established enzyme assays and provided enzymes for $X$-ray cocrystallography; $Y K$ and KDP performed inhibitor testing in the FRET enzyme assay; KOC, YK, WCG, SL prepared the original draft of the paper; KOC, YK, WCG, SP, SL reviewed and edited the paper. Competing interests: The authors declare no competing interests. Kansas State University, Wichita State University and the University of lowa have jointly filed a provisional patent application \#63001781 entitled "Broad spectrum antivirals against coronaviruses" that covers compounds $6 j$ and 6 has well as related compounds, with KOC, YK, SP and WCG as coinventors. Data and materials availability: All data associated with this study are in the main text or Supplementary Materials. Coronavirus $3 \mathrm{CLp}$ ro enzymes and inhibitors are available from Kyeong-OK Chang under a materials transfer agreement with Kansas State University. Coordinates and structure factors for the $3 C L$ pro inhibitor complexes are deposited in the Worldwide Protein Data Bank (wwPDB) with the accession codes: MERS-CoV 3CLpro with inhibitor 6b(6VGY), $6 d(6 \mathrm{VGZ}), 6 g(6 \mathrm{VH}), 6 h$ (6VH1), 7i(6VH2) and 7j(6VH3); SARS-CoV 3CLpro with inhibitor 7j(6W2A); SARS-CoV-2 3CLpro with inhibitor 7j(6XMK). This work is licensed under a Creative Commons Attribution 4.0 International (CC BY 4.0) license, which permits unrestricted use, distribution, and reproduction in any medium, provided the original work is properly cited. To view a copy of this license, visit https://creativecommons.org/licenses/by/4.0/. This license does not apply to figures/photos/artwork or other content included in the article that is credited to a third party; obtain authorization from the rights holder before using such material.

Submitted 29 April 2020

Accepted 30 July 2020

Published First Release 3 August 2020

10.1126/scitranslmed.abc5332 


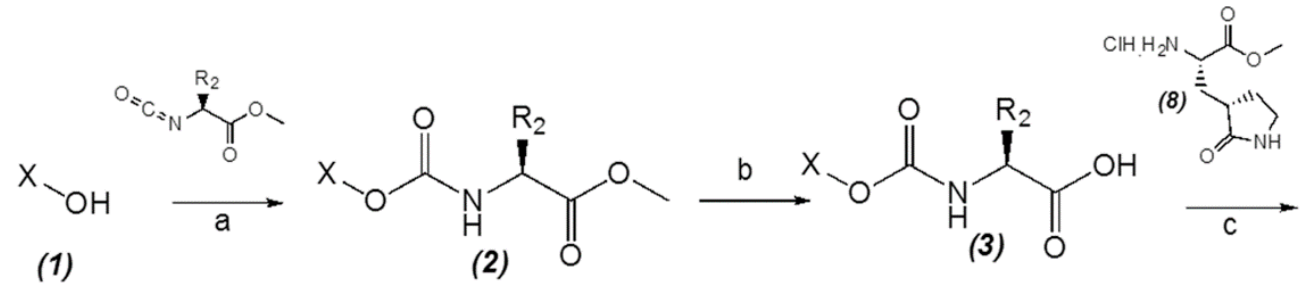<smiles>[X]OC(=O)NC([R2])C(=O)N[C@@H](C[C@@H]1CCNC1=O)C(=O)OC</smiles><smiles>[X]OC(=O)NC([R2])C(=O)N[C@@H](C=O)C[C@@H]1CCNC1=O</smiles>

Fig. 1. Synthesis scheme for compound series 6a-k and 7a-k. Stepwise compound synthesis with intermediate compounds is shown for 3CLpro inhibitors of the 6a-k and 7a-k series. The alcohol inputs were reacted with $(L)$ leucine isocyanate methyl ester or $(L)$ cyclohexylalanine isocyanate methyl ester to yield products which were then hydrolyzed to the corresponding acids with lithium hydroxide in aqueous tetrahydrofuran. Subsequent coupling of the acids to glutamine surrogate methyl ester (8) furnished compounds (4). Lithium borohydride reduction yielded alcohols (5), which were then oxidized to the corresponding aldehydes (6) with Dess-Martin periodinane reagent. The bisulfite adducts (7) were generated by treatment with sodium bisulfite in aqueous ethanol and ethyl acetate. a Amino-acid methyl ester isocyanate/TEA/ $\mathrm{CH}_{3} \mathrm{CN} /$ reflux/2 hours; ' $1 \mathrm{M} \mathrm{LiOH/THF/RT/} 3$ hours; $\quad \mathrm{EDCl} / \mathrm{HOBT} /$ glutamine surrogate/DIPEA/DMF/RT/24 hours; ${ }^{\mathrm{d}} 2 \mathrm{M}$ $\mathrm{LiBH}_{4} / \mathrm{THF} /$ methanol/RT/ 12 hours; ${ }^{e}$ Dess-Matin periodinane/DCM $/ 15^{\circ} \mathrm{C}-18^{\circ} \mathrm{C} / 3$ hours; ${ }^{\mathrm{N}} \mathrm{NaHSO}_{3}$ /ethyl acetated/ethanol $/ \mathrm{H}_{2} \mathrm{O} / 44-55^{\circ} \mathrm{C}$. Full details are provided in the Supplementary Materials and Methods. 

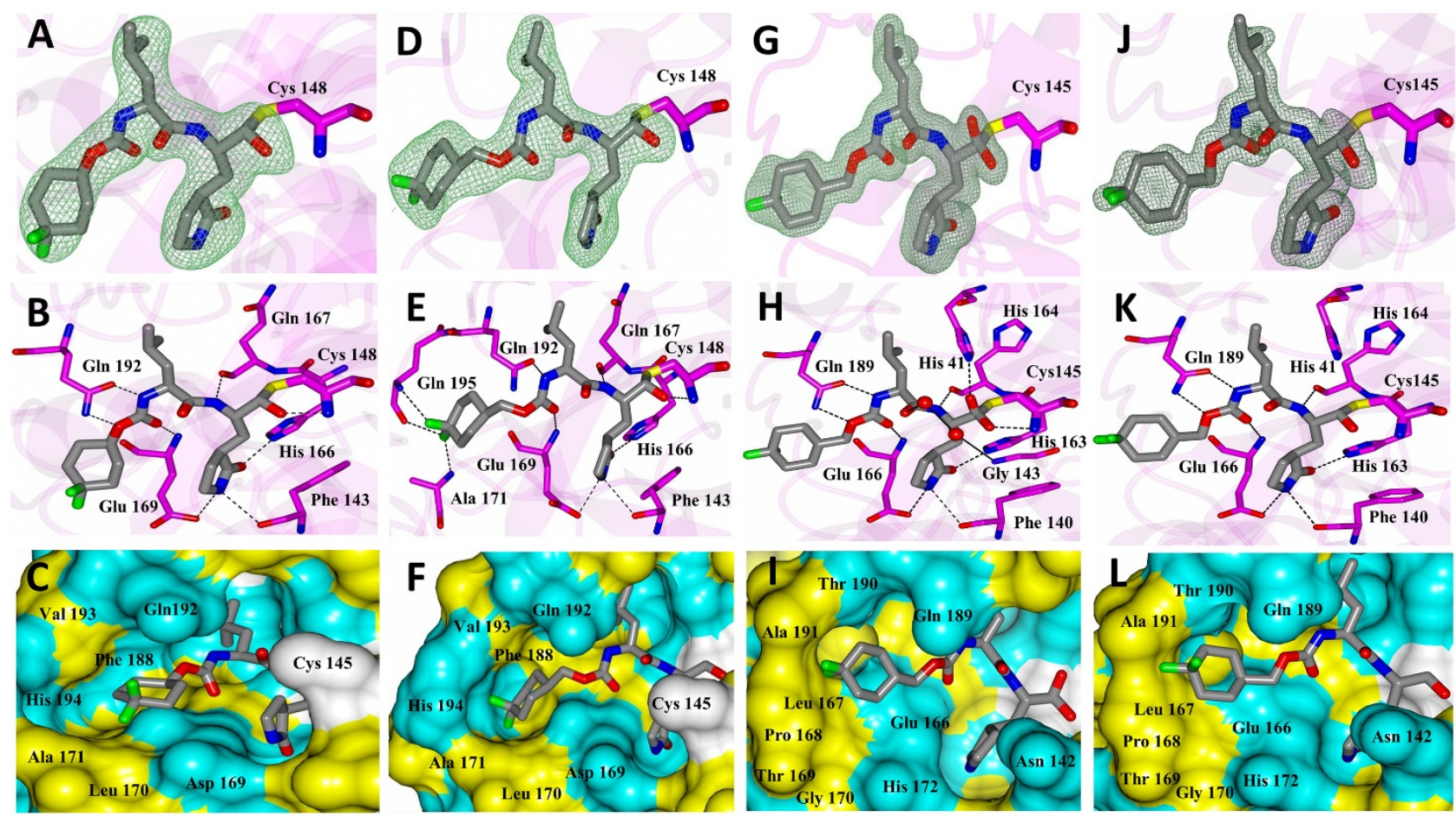

Fig. 2. X-ray cocrystal structures of compounds with coronavirus $3 \mathrm{CL}$ proteases. Shown are cocrystal structures of the MERS-CoV 3CLpro with compound $6 h$ (A, B and C) and MERS-CoV 3CLpro with compound $7 j(D, E, F)$. Shown are cocrystal structures of the SARS-CoV 3CLpro with compound

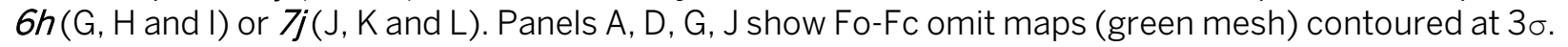
Panels $B, E, H, K$ show hydrogen bond interactions (dashed lines) between the inhibitor and the 3CLprotease. Panels C, F, I, L show electrostatic surface representation of the binding pocket occupied by the inhibitor. Neighboring residues are colored yellow (nonpolar), cyan (polar) and white (weakly polar). 

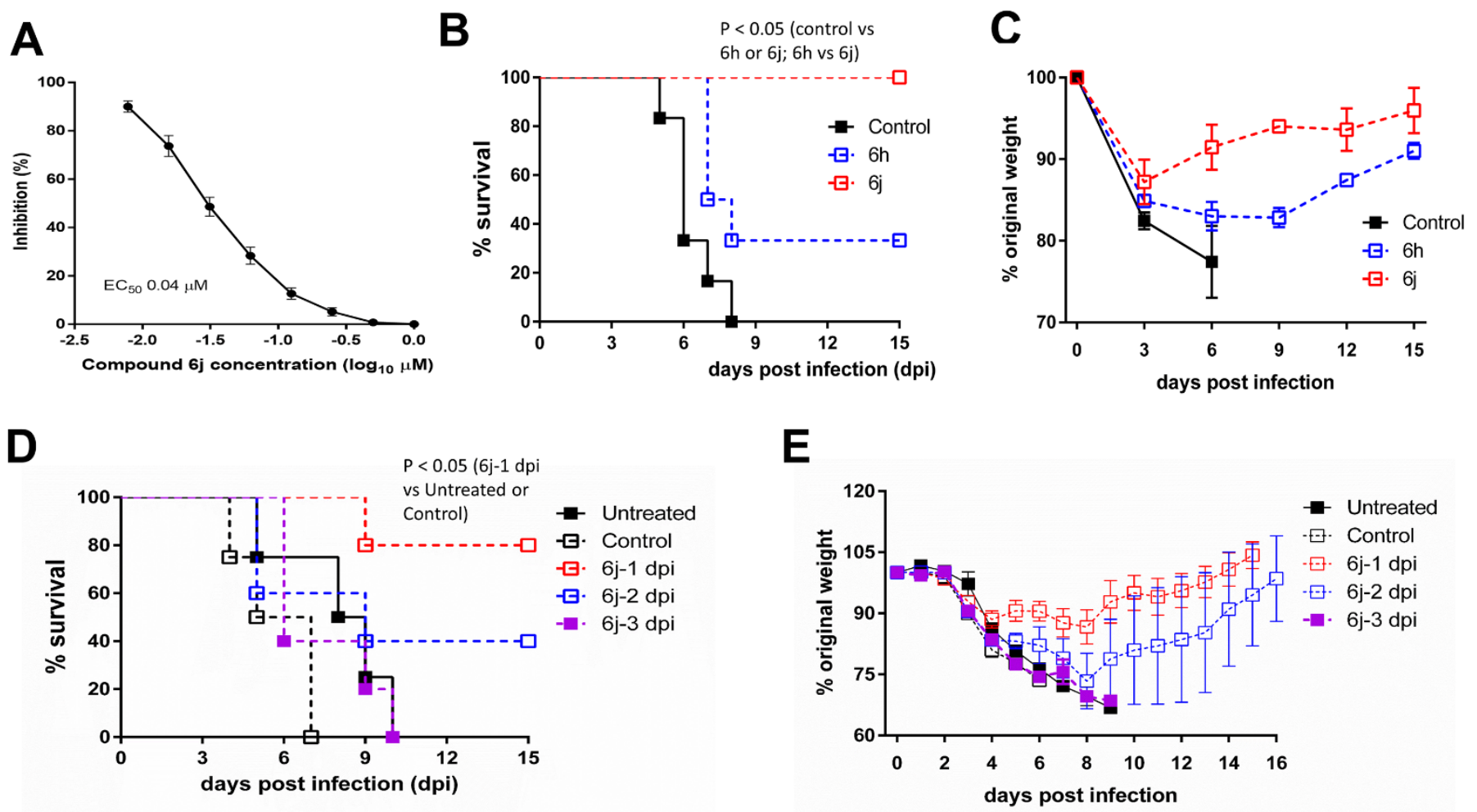

Fig. 3. Effects of treating hDPP4-KI mice infected with $M_{E R S}{ }_{M A}-\mathrm{CoV}$ with compounds 6jor $6 h$. (A) Shown is a dose-dependent curve for inhibition of MERS-CoV in cell culture by compound $6 j$. Serial dilutions of compound 6j were added to confluent Huh-7 cells, which were immediately infected with MERS-CoV at a multiplicity of infection (MOI) of 0.01 . After incubation of the cells at $37^{\circ} \mathrm{C}$ for 48 hours, viral titers were determined using a plaque forming assay and $\mathrm{EC}_{50}$ values were determined with GraphPad Prism software. (B, C) hDPP4-KI mice infected with MERS ${ }_{M A}-\mathrm{CoV}(\mathrm{n}=6)$ were treated with compounds 6jor 6h starting at 1 day post-infection (dpi) for up to 10 days and survival (B) and body weight (C) were monitored for 15 days. Control mice received vehicle only. (D, E) hDPP4-KI mice infected with MERS ${ }_{M A}-\mathrm{CoV}$ were treated with compound $6 j(\mathrm{n}=5)$ starting at $1 \mathrm{dpi}, 2$ dpi or $3 \mathrm{dpi}$, and survival (D) and body weight (E) were monitored for 15 days. Untreated mice and vehicle-treated mice $(n=4)$ were included as controls. The mice were infected with MERS $\mathrm{MA}_{-}-\mathrm{CoV}$ at $0 \mathrm{dpi}$. The data points represent the mean and the standard error of the mean for one experiment. The analysis of survival curves in groups was performed using a Log-rank (Mantel-Cox) test and Gehan-Breslow-Wilcoxon test. 
A

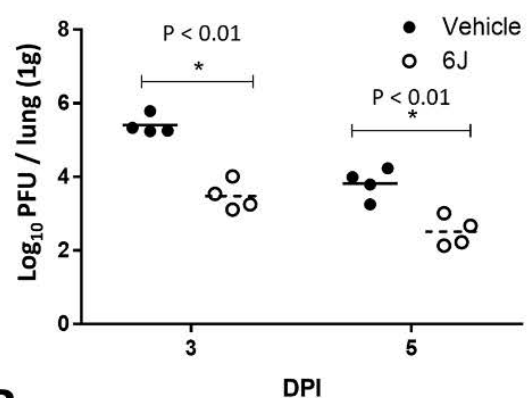

B

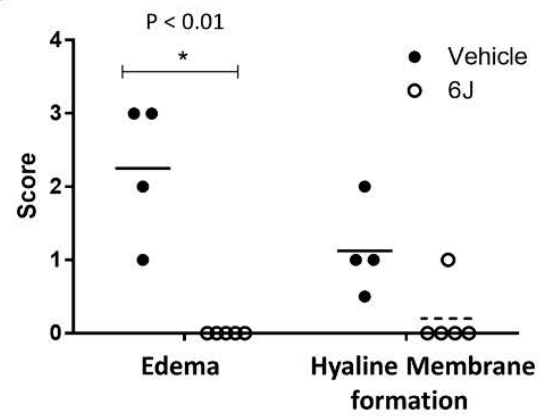

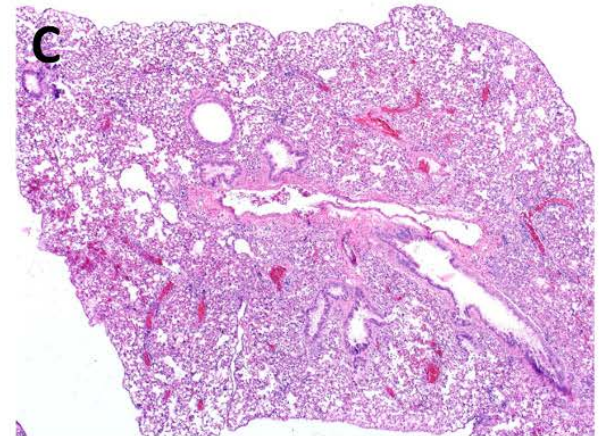


Fig. 4. Lung virus titers and histopathology of $6 j$-treated hDPP4-KI mice infected with MERS $\mathrm{MA}_{\mathrm{A}}-\mathrm{CoV}$. hDPP4$\mathrm{KI}$ mice were infected with MERS MA-CoV at 0 days post infection (dpi) and then were treated with vehicle as a control or compound 6jstarting at $1 \mathrm{dpi}$ until euthanasia ( $\mathrm{n}=4$ or 5 per group). (A) Lungs were collected and virus titers measured at 3 and 5 dpi. Lungs were examined for edema and for hyaline membrane formation (B) and lung sections were stained with hematoxylin/eosin stain for histopathology at $6 \mathrm{dpi}(\mathrm{C}-\mathrm{F})$. (B) Tissues were scored for edema and hyaline membrane formation using the scale: 0 , none; 1 , rare ( $<5$ alveoli); $2,<33 \%$ of lung fields; 3, 34-66\% lung fields, and 4, >66\% lung fields (30). (C-F) Representative histopathology images are shown for vehicle control (C, E) and compound 6jtreatment (D, F) at 40X (C, D) or 100X (E, F). Asterisks indicate $p<0.01$ by multiple $t$ tests. 
Table 1. Structures of 3CLpro inhibitors and their IC $_{50}$ values in the FRET enzyme assay.

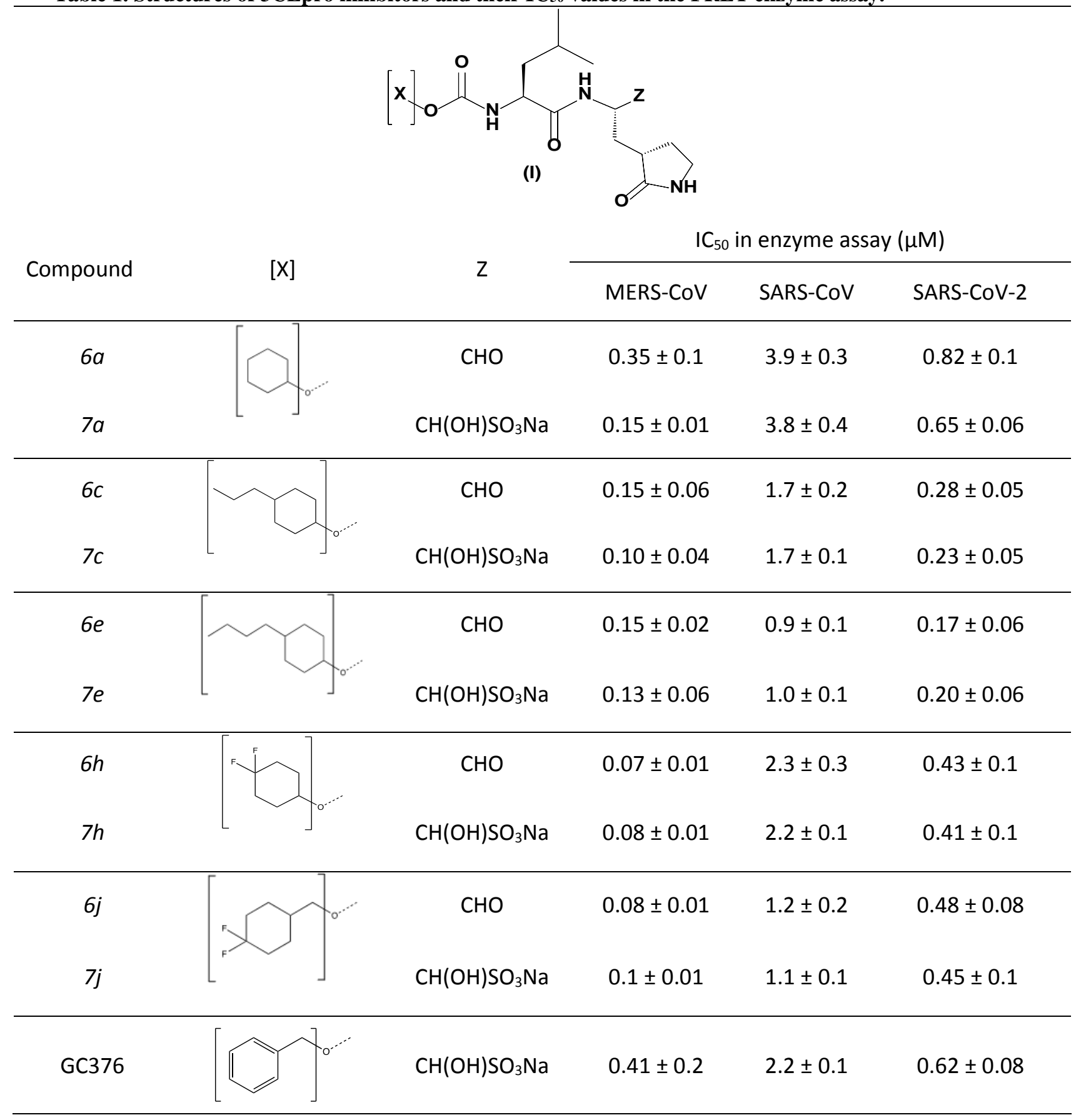


Table 2. 3CLpro inhibitors and their $\mathrm{EC}_{50}$ and $\mathrm{CC}_{50}$ values in cell culture assays.

\begin{tabular}{|c|c|c|c|c|c|}
\hline \multirow{2}{*}{ Compound } & \multicolumn{4}{|c|}{$\mathrm{EC}_{50}$ in cell culture $(\mu \mathrm{M})$} & \multirow{2}{*}{$\mathrm{CC}_{50}(\mu \mathrm{M})$} \\
\hline & MERS-CoV & SARS-CoV-2 & MHV & FIPV & \\
\hline $6 a$ & ND* & ND & $0.12 \pm 0.05$ & $0.09 \pm 0.02$ & $>100$ \\
\hline $7 a$ & $0.08 \pm 0.1$ & ND & $0.08 \pm 0.03$ & $0.07 \pm 0.02$ & $>100$ \\
\hline $6 c$ & $0.05 \pm 0.06$ & $0.25 \pm 0.15$ & $0.13 \pm 0.05$ & $0.12 \pm 0.01$ & $>100$ \\
\hline $7 c$ & ND & ND & $0.16 \pm 0.08$ & $0.17 \pm 0.03$ & $>100$ \\
\hline $6 e$ & ND & $0.15 \pm 0.14$ & $0.12 \pm 0.04$ & $0.22 \pm 0.03$ & $63.3 \pm 2.3$ \\
\hline $7 e$ & $0.53 \pm 0.2$ & ND & $0.13 \pm 0.02$ & $0.17 \pm 0.02$ & $59.1 \pm 3.5$ \\
\hline $6 h$ & ND & $0.9 \pm 0.8$ & $0.08 \pm 0.05$ & $0.12 \pm 0.05$ & $>100$ \\
\hline $7 h$ & $0.21 \pm 0.1$ & ND & $0.11 \pm 0.08$ & $0.12 \pm 0.06$ & $>100$ \\
\hline $6 j$ & $0.04 \pm 0.02$ & $0.8 \pm 0.7$ & $0.20 \pm 0.07$ & $0.08 \pm 0.02$ & $>100$ \\
\hline $7 j$ & ND & ND & $0.16 \pm 0.05$ & $0.07 \pm 0.01$ & $>100$ \\
\hline GC376" & $0.9 \pm 0.2$ & ND & $1.1^{\#}$ & $0.04^{\#}$ & $>100$ \\
\hline
\end{tabular}

* ND, not determined, the bisulfite adduct $\left(\mathrm{CH}(\mathrm{OH}) \mathrm{SO}_{3} \mathrm{Na}\right)$ reverted to the aldehyde (CHO) form and so only one form was examined in the cell-based assay; " previously reported $(13,19)$.

Table 3. Antiviral effects of compounds $6 j$ and $6 e$ against SARS-CoV-2 in cultured primary human airway epithelial cells. Study was a single experiment and viral titers were measured in duplicate with a plaque forming assay.

\begin{tabular}{|c|c|c|}
\hline Compound (concentration) & Donor Number & Virus titers $\left(\log _{10}\right)$ \\
\hline \multirow{3}{*}{ Vehicle Control } & 1 & $7.29 \pm 0.05$ \\
\hline & 2 & $7.14 \pm 0.02$ \\
\hline & 3 & $8.44 \pm 0.06$ \\
\hline \multirow{3}{*}{$6 \mathrm{j}(2.0 \mu \mathrm{M})$} & 1 & $6.35 \pm 0.02$ \\
\hline & 2 & $6.10 \pm 0.09$ \\
\hline & 3 & $6.30 \pm 0.1$ \\
\hline \multirow{3}{*}{$6 \mathrm{e}(0.5 \mu \mathrm{M})$} & 1 & $6.12 \pm 0.01$ \\
\hline & 2 & $6.50 \pm 0.01$ \\
\hline & 3 & $8.08 \pm 0.01$ \\
\hline
\end{tabular}

